\title{
FOREIGN LANGUAGE MICROTEACHING ANALYSIS
}

\section{[ANALYZA MIKROVYUCOVANIA CUDZIEHO JAZYKA]}

\begin{abstract}
Alzbeta Lobotkova
doi: 10.18355/PG.2019.8.1.2

Abstract

Nowadays we are experiencing many models of systematic observation and subsequent analysis of the educational process. Many approaches focus only on the activity of the teacher. Micro-teaching analyzes, however, give the opportunity to assess the interactional process between teacher and student, not just the result. In this regard, the research study focuses on determining the motivational influence of the teacher on students, the style of the teacher's teaching and the development of cognitive functions of students during foreign language lessons. For this reason, using the AS9 analytical scheme, we have focused on observing and recording engagement units from teacher to students during the English and German lessons. The research sample was made up of teachers from a secondary vocational school in the Trencin region. The results show that motivational action results of foreign language teachers do not respond to real motivational action due to the use of "filler words", the middle degree of directions and development of lower cognitive processes prevails.
\end{abstract}

\section{Key words}

micro-teaching analyzes, teaching lesson, foreign language, teacher's style of teaching, direction/non-direction index, motivation, motivation index, cognitive functions index

\begin{abstract}
Anotácia
V súčasnosti sa stretávame s množstvom modelov systematického pozorovania a následnej analýzy edukačného procesu. Mnoho prístupov sa orientuje iba na činnost' učitel'a. Mikrovyučovacie analýzy však dávajú možnost' posudzovat' interakčný proces medzi učitel'om a žiakom, a nie iba výsledok. V tomto zmysle sa výskumná štúdia orientuje na zistenie motivačného pôsobenia učitel'a na žiakov, štýlu učitel'ovho vedenia vyučovania a rozvíjania kognitívnych funkcií u žiakov na hodinách cudzieho jazyka. Z tohto dôvodu sme sa prostredníctvom využitia analytickej schémy AS9 zamerali na pozorovanie a zaznamenávanie interakčných jednotiek smerujúcich od učitel'a k žiakom na hodinách anglického a nemeckého jazyka. Výskumnú vzorku tvorili učitelia zo stredných odborných škôl v trenčianskom kraji. Z výsledkov vyplýva, že u učitel'ov cudzích jazykov výsledky motivačného pôsobenia nezodpovedajú skutočnému motivačnému pôsobeniu z dôvodu využívania tzv.,,barličiek“, prevláda stredný stupeň direktivity a rozvoj nižších kognitívnych procesov.
\end{abstract}




\section{Kl'účové slová}

mikrovyučovacie analýzy, vyučovacia hodina, cudzí jazyk, štýl učitel’ovho vedenia vyučovania, index direktivty/nedirektivity, motivácia, index motivácie, index kognitívnych funkcií

\section{Úvod}

Výchovno - vzdelávací proces je vel'mi zložitý proces, do ktorého vstupuje a ovplyvňuje ho vel'ké množstvo činitel'ov. Za najdôležitejšie subjekty výchovno - vzdelávacieho procesu možno označit' osobnost' učitel'a a osobnost' žiaka, ktorí svojim interakčným prístupom $\mathrm{k}$ výučbe tvoria dôležité hl'adisko v oblasti zvyšovania kvality výchovno - vzdelávacieho procesu. V súčasnosti je jednou z najvýraznejších metód zist'ovania kvality výchovno - vzdelávacieho procesu práve mikrovyučovacia analýza, prostredníctvom ktorej sa vykonáva rozbor činností, aktivít, pohybov, správania, gest, ktoré sú účastné na vyučovacej hodine. Mikrovyučovacia analýza dáva možnost' pozorovat' viacero oblastí edukácie, napríklad postupy učitel'a, zefektívnenie jeho práce, interakcia učitel' - žiak a podobne. Okrem uvedeného však pomáhajú pozorovat' aj mimopoznávacie procesy (napr. motivovanie žiakov učitel'om) Interakciu učitel'a a žiaka môžeme označit' aj ako základ cudzojazyčného vzdelávania, ktoré prebieha $\mathrm{v}$ určitých prispôsobených podmienkach a $\mathrm{v}$ podmienkach vyučovania cudzieho jazyka zohráva vel'mi významné miesto aj motivačná a emocionálna oblast' psychiky učiacich sa (žiakov).

\section{Teoretické východiská}

Bez jazyka nie je komunikácia a bez znalosti cudzieho jazyka sa nedá uskutočňovat' interkultúrna komunikácia (Průcha, J. 2010, s.107). Učitel’ovo pôsobenie nielen vo vyučovaní cudzích jazykov by sa nemalo obmedzovat' iba na spravovanie a riadenie kognitívnej/rozumovej činnosti žiakov, ale podstatné je aj upriamenie pozornosti na rad vzt’ahov, ktoré sa týkajú motivačnej oblasti. V súčasnosti sa stretávame s tou skutočnost'ou, že žiaci považujú predmet cudzí jazyk za „neoblúbený“. V nadväznosti na „neoblúbenost““ predmetu a nedostatočnú motiváciu žiakov k učeniu sa cudzích jazykov autorka A. Butašová spolu s kolektívom autorov (2007, s.106) uvádzajú nasledovné faktory, v ktorých vidia nedostatočný záujem žiakov k cudziemu jazyku:

- „Žiaci málo cestujú a nemajú väčšiu možnost' využívat' cudzie jazyky v prirodzenom cudzojazyčnom prostredí,

- cudzie jazyky neovládajú ani niektorí učitelia, dokonca v uspokojujúcej miere ani učitelia cudzích jazykov,

- vyučovanie cudzích jazykov nie je zabezpečené po materiálnej stránke,

- cudzie jazyky patria pre cca $42 \%$ žiakov medzi neobl'úbené predmety, čo je spôsobené t’ažkým zapamätávaním cudzích výrazov“.

$\mathrm{Aj}$ z uvedeného dôvodu sa zo strany učitel’ov cudzích jazykov očakáva, že budú žiakov, ktorí považujú cudzí jazyk za „neoblúbený“ predmet, motivovat' svojou dôkladnou prípravou na vyučovanie, výberom metód a foriem, využívaním digitálnych technológií, učebných materiálov a podobne. $\mathrm{V}$ kontexte prípravy učitel'a na vyučovanie cudzieho jazyka sa

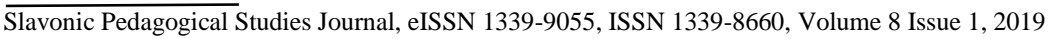


však v súčasnosti stretávame aj so základnými nedostatkami učitel’ov, ktorí terminológiu cudzieho jazyka, ktorý vyučujú neovládajú dostatočne a nemajú dostatok času sa na vyučovanie dôkladne pripravit'. Z tohto dôvodu poukazuje autorka R. Vajdičková (2013, s.22) na

nasledovné nedostatky učitel'ov cudzích jazykov:

- „neprimeraná nadväznost' jednotlivých úrovní výučby na rôznych stupňoch škôl a v rámci jednotlivých škôl,

- $\quad$ pomerne vel'ká rozmanitost' metód, foriem a učebných materiálov,

- nedostatočnost' využívania autentických materiálov,

- rovnaké požiadavky na žiakov maturitných ročníkov stredných odborných škôl a žiakov gymnázií,

- $\quad$ pretrvávajúce preferovanie memorovania slovnej zásoby a komunikácie,

- malá integrácia poznatkov u učitel'ov cudzích jazykov s obsahom učiva iného vyučovaného predmetu“.

Z uvedeného vyplýva, že v súčasnosti je nutné, aby sa venovala väčšia pozornost' rozvíjaniu takých schopností, ako je sebaovládanie, zvládanie emócií, motivácia, empatia, čo predpokladá najmä individuálny prístup $\mathrm{k}$ žiakom a uplatňovanie osobnosti učitel'a v procese výučby (Lobotková, A. 2016). Ak vychádzame z predpokladu, že ciel'om výchovno - vzdelávacieho procesu je komplexne rozvinutá osobnost', tak neoddelitel'nou súčast'ou tohto procesu sú dve základné zložky: intelektová, v ktorej dominuje kognitívna stránka osobnosti žiaka a druhou zložkou je zložka emocionálna. Vyvrcholením tvorivo - humanistickej výchovy je hl'adanie kompromisu medzi humanistickým prístupom učitel'a $\mathrm{k}$ žiakom a jeho náročnost'ou na výkony v oblasti kognitívnej a emocionálnej (Zelinová, M. 2004, s.153). V kontexte uvedeného aj Š. Švec (1997, s.135-136) rámcuje v modeli humanisticky zameranej výučby činnost' učitel'a do 10 kategórií:

1. Emocionalizácia vyučovania prostredníctvom schopností a radostí žiaka.

2. Prenášanie učitel'ovho entuziazmu a vitality na žiakov, prejavovaním sebadôvery a zdravého sebavedomia učitel'a.

3. Stimulovanie žiakov k samostatnosti a tvorivosti.

4. Rešpektovanie jedinečnosti žiakov.

5. Podporovanie žiackej sebadôvery, sebapotvrdzovania a pomoc pri rozvoji pozitívneho sebapoňatia.

6. Tolerovanie odlišných názorov, presvedčení, postojov, kultúrneho štýlu iných osôb.

7. Uprednostňovanie pozitívneho hodnotenia žiaka učitel'om a spolužiakmi, napríklad povzbudzovaním pri prežívaní neúspechu.

8. Morálna socializácia a rozvoj kultúrneho správania sa a prosociálneho konania žiakov.

9. Utváranie priaznivej socio-emočnej klímy a stimulatívneho prostredia v triede a v škole, napríklad navodením a zvládnutím situácií, ktoré umožňujú uplatnit' individuálne potreby (potreba zdravia, bezpečia, náklonnosti, porozumenia a dôvery, spolupatričnosti, uznania a úcty, aktivity a úspechu, nezávislosti a vol'nosti, potreba sebidentity). 
10. Kombinované a d'alšie znaky a prejavy humanisticko - pedagogického zamýšl'ania, cítenia a konania.

Pre učitel'a by to teda malo znamenat', že jeho pôsobenie by sa nemalo obmedzovat' iba na riadenie kognitívnej činnosti, ale najmä na vzájomný vzt'ah obsah učiva - učitel' - žiak, s upriamením pozornosti na emocionálno motivačný aspekt výučby a interakciu učitel' - žiak, ktorá je obohatená o humanistický rámec.

V nadväznosti na teoretické východiská bolo hlavným zámerom zistit' motivačné pôsobenie učitel'a na žiaka, v akej miere je zastúpená miera direktivity/ nedirektivity u učitel'ov stredných odborných škôl a rozvoj kognitívnych funkcií u žiakov na vyučovaní cudzích jazykov - anglického a nemeckého jazyka.

\section{Výskumná vzorka}

Výskumná vzorka bola tvorená učitel'mi cudzích jazykov (anglický jazyk, nemecký jazyk) zo stredných odborných škôl v trenčianskom kraji $(\mathrm{N}=4)$ (Tabul'ka 1). Konkrétne učitel'mi zo Strednej odbornej školy obchodu a služieb v Trenčíne $(\mathrm{N}=2)$ a Obchodnej akadémie v Trenčíne $(\mathrm{N}=2)$.

Tabul'ka 1 Charakteristika výskumnej vzorky (učitelia)

\begin{tabular}{|l|c|}
\hline Pohlavie & N \\
\hline Ž & 4 \\
\hline M & 0 \\
\hline Spolu & 4 \\
\hline
\end{tabular}

\section{Metódy}

Z dôvodu orientovania sa na činnosti učitel'a a posudzovania interakčného procesu medzi osobnost'ou učitel'a a osobnost'ou žiaka boli vo výskume využité analýzy mikrovyučovania, ktoré dávajú možnost' posudzovat' uvedený interakčný proces učitel' - žiak. Pri analýzach mikrovyučovania ide o rozbor konkrétnych aktivít, pohybov a správaní, ktoré sa priamo vyskytujú na vyučovacej hodine (Zelina, M. 2006).

Pri realizácii analýz mikrovyučovania bola zvolená analytická schéma AS9 ktorej autorom je M. Zelina a môžeme prostredníctvom nej sledovat' direktivitu/ nedirektivitu učitel'a, rozvíjanie kognitívnych funkcií u žiakov a motiváciu, akú vyvoláva učitel' svojimi verbálnymi reakciami u žiakov. Analytická schéma, podl'a ktorej sa vo výskume postupovalo je nasledovná:

\section{Analytická schéma AS9}

\section{A. Akceptácia žiakov}

1. Súhlas, akceptácia žiaka, alebo jeho odpovede, činu

2. Pochvala, odmena, dobrá známka, pozitívne hodnotenie žiaka alebo triedy

3. Vyslovenie dôvery žiakom, povzbudenie do činnosti

4. Zaujímavé uvedenie látky, učiva, zaujímavá úloha

5. Výzvy, apely na činnost', ale nie direktívneho charakteru 


\section{Q. Otázky učitel'a žiakom}

1. Otázky na vnímanie, senzomotoriku a pamät

2. Otázky na pochopenie, konvergentné myslenie, logické myslenie (príčinnost', analýza, syntéza, aplikácia, zovšeobecnenie, dedukcia, indukcia)

3. Otázky na hodnotiace myslenie (podnety, ktoré vyzývajú žiaka niečo hodnotit', zaujat' svoj postoj. Môže to byt' v oblasti racionálnej: správne - nesprávne; v oblasti etickej: dobré - zlé; v oblasti estetickej: krásne škaredé. Patrí sem hodnotenie výkonu, správania žiakov žiakmi, ked' dá a to podnet učitel'.)

4. Otázky a podnety na tvorivé, divergentné myslenie

5. Otázky žiakov pedagógovi (osobné, organizačné, tematické, otázky na postup práce)

\section{R. Negatívne hodnotenie žiakov}

1. Negatívne hodnotenie, kritika, nesúhlas so žiakom

2. Opravy, korekcie

3. Irónia, sarkazmus, výsmech, nadávanie žiakom

4. Ponižovanie, trestanie

5. Chýbajúce hodnotenie výkonu žiaka po jeho odpovedi, výkone

\section{T. Hovorenie učitel'a}

1. Pokyny na prácu, organizačné pokyny

2. Príkazy, dirigovanie, nariadenia, povely

3. Vysvetl’ovanie látky, výklad učiva, prednáška

4. Neodôvodnené rozprávanie, odbiehanie od témy, opakovanie už povedaného, zdôrazňovanie autority učitel’a - „JA“

5. Poúčanie, moralizovanie, „kázanie“

6. Jazykové, komunikačné prehrešky: „barličky“ - opakované slová, echá - opakovanie odpovedí žiakov, nespisovné výrazy, rýchla reč, nejasná reč, zložité vety, cudzie slová,...

P. Gavora (2012, s.65) uvádza, že pri realizácii analýz mikrovyučovania má pozorovatel' k dispozícii pozorovací hárok, ktorý riadi jeho pozorovanie, a do ktorého zaznamenáva výskyt pozorovaných javov. Do záznamového hárku sme z nahrávok zaznamenávali interakčné jednotky - vety, ktoré vyslovil učitel žiakom. Po sčítaní jednotlivých uvedených interakčných jednotiek v záznamovom hárku získavame celkový profil správania sa učitela v priebehu vyučovania a počítajú sa príslušné indexy. Jedná sa o index direktivity, index motivácie a index kognitívnych funkcií (Obrázok 1). 


$$
\mathbf{I k f}=\frac{\mathbf{Q 3 + Q 4}}{\mathbf{Q 1 + Q 2}}
$$

\section{Obrázok 1Vzorce na výpočet indexu direktivity, indexu motivácie a indexu kognitívnych funkcií}

Index direktivity je zameraný na sledovanie učitel'ovho štýlu edukácie. Vzorec zodpovedajúci uvedenému indexu tvorí A (motivácia, oceňovanie a povzbudzovanie žiakov), Q (otázky na rozvoj kognitívnych procesov), R (negatívne hodnotenie žiakov) a T (rozprávanie učitel'a, napríklad výklad nového učiva, organizačné pokyny, pokyny na prácu). Delenie stupňov direktivity podl'a M. Zelinu (2006, s.103):

0,1-0,5 = vysoko direktívny učitel'

$0,51-0,79=$ stredný stupeň direktivity

$0,80-1,00=$ nižší stupeň direktivity

$1,01-2,5=$ nedirektívny učitel'

2,6- a viac = vysoko nedirektívny učitel'

Index motivácie je zameraný na sledovanie motivujúcich a demotivujúcich reakcií učitel'ov smerom k žiakom. Vzorec zodpovedajúci indexu motivácie tvorí A (akceptácia žiakov - pozitívna motivácia), R (negatívne hodnotenie žiakov - negatívna motivácia).

Index kognitívnych funkcií je zameraný na sledovanie podnetov a otázok rozvíjajúcich pamät', vnímanie (Q1), konvergentnté myslenie, logické myslenie (Q2), hodnotiace myslenie (Q3), tvorivé, divergentné myslenie (Q4) (Lobotková, 2016). Aj v tomto prípade, ak učitel' dosiahne hodnotu nižšiu ako 1,0 možno tvrdit', že dával žiakom podnety a úlohy, ktoré rozvíjali nižšie kognitívne procesy. Naopak, ak dosiahne hodnotu nad 1,0, dával žiakom podnety a úlohy, rozvíjajúce vyššie kognitívne procesy (Zelina, M. 2006).

\section{Výsledky}

Prostredníctvom analýz mikrovyučovania bol s použitím analytickej schémy AS9 sledovaný štýl edukácie učitel'ov cudzích jazykov, rozvíjanie kognitívnych procesov u žiakov a motivácia, ktorú vyvoláva učitel' svojimi verbálnymi reakciami na predmetoch cudzieho jazyka - anglického a nemeckého jazyka. U jednotlivých učitel'ov boli nahrávané 2 vyučovacie hodiny. V konečnom dôsledku bolo nahratých 8 vyučovacích hodín na stredných školách u 4 učitel'ov. Na každej vyučovacej hodine bol priebeh 
vyučovania sledovaný osobne, čím bolo uskutočnené priame a komplexné pozorovanie. Následne prebiehala realizácia prepisu z diania vyučovacej hodiny a podl'a zvolenej analytickej schémy (AS9) kódovanie a zarad'ovanie jednotlivých interakčných jednotiek. Na základe početnosti jednotlivých interakčných jednotiek $\mathrm{v}$ oblastiach sa počítal index direktivity, index motivácie a index kognitívnych funkcií pre príslušných učitel’ov. Výsledky analýzy sú prezentované nižšie.

Tabul'ka 2Hodnoty indexov (direktivity/nedirektivity, motivácie, kognitívnych funkcií) pre jednotlivých učitel'ov

\begin{tabular}{|l|c|c|c|}
\hline & Id & Im & Ikf \\
\hline Učitel' 1 & 0,50 & 1,82 & 0,72 \\
\hline Učitel' 2 & 1,05 & 1,39 & 0,28 \\
\hline Učitel' 3 & 1,12 & 1,95 & 0,18 \\
\hline Učitel' 4 & 0,68 & 1,72 & 0,16
\end{tabular}

*Pozn.: Id - index direktivity, Im - index motivácie, Ikf-index kognitívnych funkcií

V tabul'ke 2 sú prezentované hodnoty jednotlivých indexov (direktivity/ nedirektivity, motivácie, kognitívnych funkcií) pre jednotlivých učitel’ov. $Z$ výsledkov uvedených hodnôt vyplýva u jednotlivých učitel'ov nasledovné:

Učitel' 1 - z hodnôt uvedených $v$ tabul'ke 2 vyplýva, že učitel' vo vel'kej miere motivoval žiakov, bol vysoko direktívny a rozvíjal nižšie kognitívne procesy. Kvantitatívne analýzy mikrovyučovania však dopĺňam kvalitatívnou analýzou.

Aj napriek tomu, že bolo u Učitel’a1 komplexne za celú kategóriu A zaznamenaných $\mathrm{v}$ priemere 7.1 akceptujúcich reakcií, dopíñam túto skutočnost' kvalitatívnou analýzou najmä z toho dôvodu, že učitel' na hodine používal slová súhlasov, pochvál a odmien ako svoju „barličku“ [...,,dobre“; „dobre správne“; „hej, dobre“;...], čo sa odzrkadlilo aj na výslednom indexe motivácie.

Index direktivity má hodnotu nižšiu ako 1.0, čo bolo spôsobené najmä početnost'ou interakčných jednotiek za negatívne hodnotenie žiakov, konkrétne za oblast' R1(negatívne hodnotenie, nesúhlas so žiakmi) a R2 (opravy a korekcie) a početnost'ou interakčných jednotiek za kategóriu hovorenia učitel'a, najmä v oblasti T1 a T2, kedy prostredníctvom príkazov a nariadení vyzýval a upozorňoval žiakov na nedostatky, čo sa odrazilo aj na jeho nedostatočnej motivácii.

Vzhl'adom na skutočnost', že učitel' počas svojich hodín upriamoval pozornost' na výklad učiva a preferoval pokyny, povely na prácu, nariadenia a príkazy, sa nepriaznivo prejavilo v oblasti rozvoja kognitívnych funkcí́. Azda najpriaznivejšie sa prejavili otázky smerujúce na pochopenie 
preberaného učiva. Počas expozičnej fázy vyučovacieho procesu, v priebehu vysvetl'ovania nového učiva sa učitel' neustále pýtal žiakov otázky typu [,rozumiete? Môžem pokračovat' d'alej?"; ,,...pýtajte sa ak niečomu nerozumiete"; ,,...pochopili ste? “;...]. Index kognitívnych funkcií dosiahol hodnotu pod 1.0, konkrétne 0,72 na základe čoho možno tvrdit', že učitel' dával podnety a otázky žiakom rozvíjajúce nižšie kognitívne procesy.

Učitel' 2 - z hodnôt uvedených $v$ tabul'ke 2 vyplýva, že učitel' žiakov motivuje, preferuje nedirektívne vedenie vyučovania a rozvíja nižšie kognitívne procesy.

$\mathrm{Aj}$ napriek tomu, že bolo u Učitel'a2 komplexne za celú kategóriu $\mathrm{R}$, za oblast' negatívneho hodnotenia zaznamenaných oproti ostatným učitel'om najviac, t.j. $\mathrm{v}$ priemere 4,8 interakčných jednotiek $\mathrm{v}$ našom prípade neznamená, že učitel' nerozvíjal u žiakov motiváciu. Vyplývajúc z tej skutočnosti, že bola u učitel'a zaznamenaná vysoká početnost' za organizačné pokyny a pokyny na prácu, sa vo vel'kej miere prejavilo $\mathrm{v}$ súhlasoch a akceptáciách odpovedí žiakov.

Táto skutočnost' sa prejavila aj na výslednom indexe direktivity, kde sa preukázalo, že učitel' preferuje nedirektívne vedenie vyučovania. Index má hodnotu nad $1.0(\mathrm{Id}=1,05)$, čo bolo spôsobené najmä vysokým číslom za súhlasné a akceptujúce reakcie učitel’a smerom $\mathrm{k}$ žiakom (A1) a nízkymi hodnotami za oblast' $\mathrm{R}$ (negatívne hodnotenie). Vysoká hodnota bola u učitel'a dosiahnutá aj v kategórii Q, konkrétne Q1 a Q2, čo sa však odrazilo aj na výslednom indexe kognitívnych funkcií.

Najmä v úvodnej fáze vyučovacieho procesu, počas opakovania, a vo fixačnej etape vyučovacieho procesu, kedy učitel' kládol učitel' žiakom otázky na zopakovanie preberaného učiva čo zodpovedá indexu kognitívnych funkcií, ktorý dosiahol hodnotu pod 1.0. To znamená, že učitel' aj v tomto prípade rozvíjal najmä nižšie kognitívne procesy $(\mathrm{Ikf}=0,27)$.

Učitel' 3 - z hodnôt uvedených $\mathrm{v}$ tabul'ke 2 vyplýva, že učitel' rozvíja u žiakov motiváciu, preferuje nedirektívne vedenie vyučovania a rozvíja nižšie kognitívne procesy.

$\mathrm{Z}$ pozorovania priemerov za celú kategóriu $\mathrm{A}$ a za celú kategóriu $\mathrm{R}$ vyplýva, že Učitel'3 vo väčšej miere preferoval najmä súhlasné a akceptujúce reakcie $v$ porovnaní s využívaním negatívnych hodnotení. Učitel' pôsobil uvol’neným dojmom a index motivácie bol spôsobený najmä vysokým číslom za A1 a A5. Najvyššiu početnost' za kategóriu R, získal najmä v oblasti R5, kedy absentovala akákol'vek reakcia učitel’a. Učitel' $v$ motivačnej fáze vyučovacieho procesu vzbudil záujem žiakov o nové učivo (pieseň GANGNAM STYLE), ktorú následne $\mathrm{v}$ expozičnej fáze spoločne analyzovali. Žiaci sa aktívne zapájali, učitel' mal stanovené spôsoby ako pristupovat' $\mathrm{k}$ žiakom, ako ich vyzývat' k činnosti.

Vyššie uvedený spôsob výučby aký učitel' preferoval, sa prejavil aj na výslednom indexe direktivity, kde sa potvrdilo, že učitel' preferoval nedirektívny spôsob vedenia vyučovania. Aj v tomto prípade bol index, ktorý dosiahol hodnotu nad $1.0(\mathrm{Id}=1,12)$, spôsobený najmä vysokým číslom za súhlasné a akceptujúce reakcie učitela smerom k žiakom (A1) a nízkymi 
hodnotami za oblast' R, za negatívne hodnotenie. Aj Učitel'3 vysokú hodnotu dosiahol v kategórii Q, konkrétne Q1 a Q2. Otázky na logické myslenie a pochopenie kládol žiakom najmä $\mathrm{v}$ expozičnej časti vyučovacieho procesu, čím získali správne predstavy o učive a o osvojení si učiva, a dbal najmä na aktivitu a aktívne zapájanie žiakov. Kladenie otázok na pochopenie a logické myslenie sa však odrazilo aj na výslednom indexe kognitívnych funkcií. Aj v tomto prípade hodnota indexu kognitívnych funkcií, ktorá dosiahla hodnotu pod 1.0 znamená, že učitel' rozvíjal nižšie kognitívne procesy $(\mathrm{Ikf}=0,18)$.

Učitel' 4 - z hodnôt uvedených $\mathrm{v}$ tabul'ke 2 vyplýva, že učitel' žiakov motivuje, prevažuje u neho stredný stupeň direktivity a rozvíja nižšie kognitívne procesy.

Podobne tak ako Učitel'1, aj Učitel'4 využíval v priebehu vyučovania „barličky“. Učitel’ striktne inštruoval žiakov a rázne vyzýval žiakov $\mathrm{k}$ odpovediam, stereotypne využíval slovíčka typu „,dobre“; áno dobre“, „hej“. Týmto sa zvýšil počet za kategóriu A, ktorý však nezodpovedá jeho skutočnému motivačnému pôsobeniu. Aj napriek tomu, že sa učitel' snažil povzbudzovat' žiakov, malo to skôr negatívny dopad, snažil sa vel'mi rýchlo preberat' učivo [,pod'me, pod'me snažte sa pisat' rýchlejším tempom "; „,pod'me chcem to s vami postíhat' prejst" ";...]. Nadobúdala som pocit, že učitel' sa snažil prebrat' vel'mi vel'a učiva za 45 -minútovú vyučovaciu hodinu. Aj v prípade Učitel'a4 sa vo vel'kej miere zaznamenali nonverbálne reakcie, avšak negatívneho charakteru. Neustále napomínanie žiakov sa prejavovalo najmä tlieskaním učitel'a, priložením prsta $\mathrm{k}$ ústam, zaháňaním sa. Aj tieto faktory sa odzrkadlili na výslednom indexe direktivity, ktorý zodpovedá strednému stupňu direktivity $(\mathrm{Id}=0,68)$. Tento bol spôsobený najmä vysokým číslom v kategórii $\mathrm{T}$, konkrétne T1 a T2.

Aj využívanie príkazov, výklad nového učiva sa negatívne odzrkadlilo na rozvoji kognitívnych funkcií. Azda najpriaznivejšie sa prejavil rozvoj kognitívnych funkcí iba v oblasti Q1 a Q2. Aj v tomto prípade kládol otázky na pochopenie a logické myslenie iba $\mathrm{v}$ obmedzenej miere, najmä vo fixačnej fáze vyučovacieho procesu, pričom otázky na pamät' prevažovali už $\mathrm{v}$ expozičnej, počas vysvetl'ovania [,,aký má člen Wasser, to sme mali už na minulej hodine “;...]. Vyplývajúc z toho, že učitel' využíval predovšetkým otázky a podnety na pamät', pochopenie, v obmedzenej miere na logické myslenie, rozvíjal u žiakov nižšie kognitívne procesy. Tomu zodpovedá aj dosiahnutá hodnota Ikf $(0,16)$ (Lobotková, A. 2016).

\section{Diskusia}

Ciel'om výskumnej štúdie bolo zistit' motivačné pôsobenie učitel’a na žiaka, do akej miery je zastúpená miera direktivity / nedirektivity u učitel'ov stredných odborných škôl jazykov a rozvoj kognitívnych funkcií u žiakov pri vyučovaní cudzích. Resp. ciel’om bolo na základe analýz mikrovyučovania zistit' index direktivity/ nedirektivity, index motivácie a index kognitívnych funkcií jednotlivých učitel'ov $\mathrm{v}$ zmysle prístupu $\mathrm{k}$ žiakom. Aj výsledky výskumov C. H. Edwardsa a V. Wattsa (2008) poukazujú na to, že medzi osobnost'ou učitel'a a osobnost'ou žiaka by mal existovat' pozitívny vzt'ah, ktorý je základnou zásadou nedirektívneho prístupu učitel’a $\mathrm{k}$ žiakom. Aj z tohto dôvodu M. Zelina (2006, s.27) uvádza, že učitel' by mal byt' k svojim 
žiakom menej direktívny, skôr nedirektívny, citovo angažovaný, empatický a s vysokou, diferencovanou náročnost'ou. Učitel' tak môže zabezpečit' akékol'vek učebné materiály pre žiakov, bez ohl'adu na predmet a budú pre žiakov zaujímavé a vzrušujúce. $\mathrm{Na}$ základe početnosti jednotlivých interakčných jednotiek $\mathrm{v}$ jednotlivých oblastiach som počítala index direktivity/ nedirektivity, index motivácie a index kognitívnych funkcií pre príslušných učitel’ov cudzích jazykov. Na základe jednotlivých výsledkov som dospela $\mathrm{k}$ záveru, že u $50 \%$ učitel'ov prevláda nedirektívny štýl edukácie, konkrétne u Učitel'a2 a u Učitel'a3. U Učitel'a1 a u Učitel'a4 bol zastúpený direktívny štýl edukácie, ktorý sa odrazil najmä oblast’ou hovorenia učitel'a (pokyny na prácu, vysvetl'ovanie, výklad učiva, príkazy). Od učitel'a sa však očakáva, že bude žiakov v priebehu vyučovania sledovat' a bude vediet' predne diagnostikovat' aj ich motiváciu, pretože význam motivácie k učebnej činnosti na vyučovaní je nezanedbatel'ný. Na základe výsledkov vyplýva, že iba u Učitel'a2 a u Učitel'a3 motivácia žiakov zodpovedá skutočnému motivačnému pôsobeniu. Učitelia žiakov zapájali do činností na vyučovacej hodine, dávali žiakom súhlasné a akceptujúce reakcie. $Z$ výsledkov vyplýva, že všetci učitelia rozvíjajú iba nižšie kognitívne procesy. Aj M. Zelinová (2004, s.142) uvádza, že, paradoxom vzdelávacieho procesu v tradičnej škole je, že sa vo väčšine prípadov využívajú podnety iba na rozvoj nižších kognitívnych procesov a rozvoj vyšších kognitívnych procesov sa zanedbáva.

\section{Bibliographic references}

BUTASOVA, A. a kol. 2007. Koncepcia vyucovania cudzich jazykov v zakladnych a strednych skolach. Bratislava: Statny pedagogicky ustav. ISBN 978-80-89225-31-6.

CHODERA, R. 2006. Didaktika cizich jazyku. Uvod do vedniho oboru. Praha: ACADEMIA. ISBN 80-200-1213-3.

GAVORA, P. 2012. Tvorba vyskumneho nastroja pre pedagogicke badanie. Bratislava: SPN. ISBN 978-80-10-02353-0.

LOBOTKOVA, A. 2016. Analyza vyucovacej hodiny v kontexte ucebnej motivacie ziakov: dizertacna praca. Nitra: UKF, $190 \mathrm{p}$.

PRUCHA, J. 2010. Interkulturni komunikace. Praha: GRADA PUBLISHONG. ISBN 978-80-247-3069-1.

SVEC, S. 1997. Ponatie osobnosti v humanistickom ucitelstve. In: Pedagogika, roc. XLIV, pp. 129-137. ISSN 0031-3815.

VAJDICKOVA, R. 2013. Tvorba projektu a rozvoj prezentacnych zrucnosti - spolocny zaklad pre vyucbu cudzich jazykov. In: Cudzie jazyky v slovenskom vzdelavacom systeme a politika viacjazycnosti v Europskej unii, pp. 16-26. ISBN 978-80-228-2533-7.

ZELINA, M. 2006. Kvalita skoly a mikrovyucovacie analyzy. OG Vydavatelstvo Polana, spol. s r.o. ISBN 80-89192-29-7.

ZELINOVA, M. 2004. Vychova cloveka pre nove millennium. Teoria a prax tvorivo - humanistickej vychovy. Rokus. ISBN 80-89055-48-6. 
Mgr. Alžbeta Lobotková, PhD.

Department of Pedagogy

FF UCM

University of SS. Cyril and Methodius in Trnava

Námestie J. Herdu2

91701 Trnava

alzbeta.lobotkova@ucm.sk 